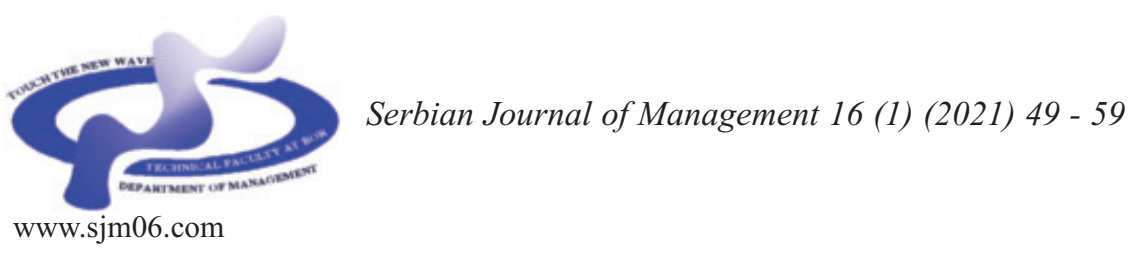

Serbian

Journal

\title{
INCLUSION OF UNCERTAINTY WITH DIFFERENT TYPES OF FUZZY NUMBERS INTO DEMATEL
}

\author{
Tjaša Šmidovnik and Petra Grošelj* \\ University of Ljubljana, Biotechnical Faculty, \\ Jamnikarjeva ulica 101, 1000 Ljubljana, Slovenia \\ (Received 04 January 2021; accepted 01 March 2021)
}

\begin{abstract}
Nowadays the multi-criteria decision making is very complicated due to uncertainty, vagueness, limited sources, knowledge and time. The Decision-making Trial and Evaluation Laboratory (DEMATEL) method is a widely used multi-criteria decision-making method to analyze the structure of a complex system. It is useful in analysing the cause and effect relationships between the components of the system. Fuzzy sets can be used to include uncertainty in multi-criteria decision making. Linguistic assessments of decision makers can be translated into fuzzy numbers. In this study, fuzzy numbers, intuitionistic fuzzy numbers and neutrosophic fuzzy numbers were used for the decision makers evaluations in the DEMATEL method. The aim of this study was to evaluate how different types of fuzzy numbers affect the final results. An application of risk in construction projects was selected from the literature, where seven experts used a linguistic scale to evaluate different criteria. The results showed that there are only slight differences between the weights of the criteria with regard to the type of fuzzy numbers.
\end{abstract}

Keywords: DEMATEL, fuzzy sets, intuitionistic fuzzy sets, neutrosophic fuzzy sets

\section{INTRODUCTION}

Real world multi-criteria decision-making is very complex today. The main reasons for this are the complexity of the problems, the uncertainty inherent in information and human thinking, the limitation of knowledge of decision makers and time constraints
(Sotoudeh-Anvari, 2020). One of the problems is that decision makers are often unable or unwilling to give precise values in the evaluation process. They tend to make assessments in the linguistic terms such as: "bad", "medium", "good", "very good" rather than in numbers (Chen \& Yang, 2011). There are different types of uncertainty. One

\footnotetext{
*Corresponding author: petra.groselj@bf.uni-lj.si
}

DOI: 10.5937/sjm16-30160 
possible classification is that of vagueness and ambiguity (Tavana et al., 2013). Vague data are not detailed or precise, and ambiguous data can have multiple interpretations. The fuzzy set theory (Zadeh, 1965) has proven to be effective in dealing with the uncertainty of human judgments. Fuzzy sets can deal with uncertain, incomplete and unavailable information. In the process of evaluating criteria or alternatives, linguistic assessments are translated into fuzzy numbers. The ranking is then based on the chosen decision method and fuzzy number operations. Fuzzy sets are defined by membership functions with grade between 0 and 1 . In order to model different types of uncertainties more reliably, several extensions of fuzzy sets have been developed: intuitionistic fuzzy sets (Atanassov, 1986), hesitant fuzzy sets (Torra \& Narukawa, 2009), neutrosophic fuzzy sets (Smarandache, 1998), etc. and their interval, soft, dual and other variations. Intuitionistic fuzzy sets are a generalization of fuzzy sets and are characterized by membership and non-membership functions with a sum less than or equal to 1. Neutrosophic fuzzy sets are a generalization of intuitionistic sets and introduce an indeterminacy membership function in addition to the membership and non-membership function.

Decision Making Trial and Evaluation Laboratory (DEMATEL) (Gabus \& Fontela, 1973) is one of the well known multi-criteria decision making methods, which can take into account the interrelation between the criteria and visualize the causal relationship. It has been used in various fields such as computer science, engineering, business and management, decision sciences, social sciences, mathematics, environmental sciences, medicine, economics, energy and others (Sheng-Li et al., 2018). The decision makers assess the influence between the criteria on the basis of the evaluation scale, which usually comprises five levels and ranges from no influence to very high influence. Since crisp values are more difficult to reflect human thinking, DEMATEL was combined with fuzzy logic and all types of fuzzy sets and their variations. However, excessive fuzzification can introduce unnecessary complexity into the decision making process (Opricovic \& Tzeng, 2003).

The aim of this paper is to investigate how different types of fuzzy sets in combination with DEMATEL influence the results of decision making. We investigated whether more sophisticated types of fuzzy numbers such as intuitionistic or neutrosophic fuzzy numbers have a positive influence on the final results. We selected an example from the literature (Vafadarnikjoo et al., 2016) and compared the results obtained by including different types of fuzzy sets in DEMATEL.

\section{METHODS}

\subsection{DEMATEL}

DEMATEL was first developed by the Geneva Research Centre of the Battelle Memorial Institute to visualize the structure of complicated causal relationships by means of matrices of digraphs. It is useful in analysing the cause- and effect- relationships between the components of the system. Due to its advantages, DEMATEL has received much attention in the last decade. Many researches have used it to solve complicated system problems in various fields.

DEMATEL consists of several steps:

Step 1: The first step involves identifying decision objectives, identifying the criteria 
relevant to the problem and selecting experts and decision makers with good experience and knowledge in the relevant decisionmaking area.

Step 2: Generate the direct-influence matrix D: Experts assess the influence between each pair of criteria. The pairwise assessment scale is divided into five levels: no influence (NI), very low influence (VLI), low influence (LI), high influence (HI) and very high influence (VHI). The linguistic terms are then represented by the grades 0,1 , 2, 3 and 4 (Table 1). The assessments of $m$ experts are arranged in direct matrices, $D^{k}=$ $\left[d^{k}{ }_{i j}\right]$, where $D^{k}$ is $n \times n$ matrix and $d^{k}{ }_{i j}$ indicates the assessments of expert $k$ in relation to the direct influence of factor $i$ on factor $j$. All principal diagonal elements $d^{k}{ }_{i j}$ of the matrices $D^{k}$ are zero. The group direct matrix $D=\left[d_{i j}\right]$ is a mean value of matrices $D^{k}$, where its elements $d_{i j}$ are the arithmetic mean of elements $d_{i j}^{k}, k=1, \ldots, m$.

Step 3: Normalize the initial directrelation matrix D. $X=\left[x_{i j}\right]$ is the normalized direct-relation matrix, where $x_{i j}$ is calculated as follows

$$
x_{i j}=\frac{d_{i j}}{\max _{1 \leq i \leq n} \sum_{j=1}^{n} d_{i j}}, i, j=1, \ldots, n .
$$

Step 4: Calculate the total-relation matrix $T=\left[t_{i j}\right]$ :

$$
T=X(I-X)^{-1}
$$

where $I$ is an identity matrix.

Step 5: Construct the causal diagram: The row sums $R_{i}$ and the column sums of $C_{j}$ the total relation matrix are calculated as follows

$$
R_{i}=\sum_{j=1}^{n} t_{i j}, i=1, \ldots, n,
$$

$$
C_{j}=\sum_{i=1}^{n} t_{i j}, j=1, \ldots, n
$$

$R_{i}$ represents the total influence that factor $i$ exerts on the other factors, while $C_{j}$ represents the total influence that factor $j$ receives from all other factors. If $i=j$, the sum $R_{i}+C_{i}$ (Prominence value) indicates the total effects given and received by factor $i$. The difference $R_{i}-C_{i}$ (Relation value) represents the net effect that factor $i$ contributes to the system. The causal diagram is developed, by $R_{i}+C_{i}$ on the horizontal axis representing the importance of a factor, while $R_{i}-C_{i}$ on the vertical axis divides the factors into cause (with positive values) and effect (with negative values) classes.

The importance weights of the criteria (Baykasoğlu et al., 2013; Li et al., 2020; Zhou et al., 2018) can be calculated as follows

$$
u_{i}=\sqrt{\left(R_{i}+C_{i}\right)^{2}+\left(R_{i}-C_{i}\right)^{2}}, i=1, \ldots, n
$$

and then normalized.

\subsection{Fuzzy sets and fuzzy DEMATEL}

Many decisions are associated with inaccuracies due to goals, constraints and actions that are not precisely known. Judgments for decision-making are often given by crisp values, although crisp values are an inadequate reflection of situationrelated vagueness. Zadeh (1965) introduced the fuzzy set theory in which uncertainty was expressed by this theory. In fuzzy set theory each number between 0 and 1 indicates a partial truth.

Let $X$ be a space of objects, where a generic element of $X$ is denoted by $x$. A fuzzy 
set $\tilde{A}$ in $X$ is characterized by a membership function $\mu_{\hat{A}}(x)$ representing the grade of membership of the element $x$ in $\tilde{A}$.

$$
\begin{aligned}
& \tilde{A}=\left\{\left(x, \mu_{\tilde{A}}(x)\right) \mid x \in X\right\}, \\
& \mu_{A}(x): \mathrm{X} \rightarrow[0,1]
\end{aligned}
$$

The membership functions can have different shapes, such as triangular, trapezoidal or Gaussian. Triangular fuzzy numbers (TFNs) are used to express human linguistic evaluations. TFNs are convenient to use because of their simple calculations. They are very often used in fuzzy MCDM. TFN is defined as a triplet $\tilde{A}=(l, m, u)$ with $l$ and $u$ as the lower and upper bounds, $m$ as the center of the TFNs. In the fuzzification process linguistic evaluations are converted into TFNs. Membership functions are used to assign a grade to each linguistic term.

One of the problems with calculating with fuzzy numbers is that fuzzy numbers are not suitable for matrix operations (Zhou et al., 2011). However, the DEMATEL method is based on matrix operations. The main problem with DEMATEL is the calculation of the inverse matrix of TFNs. The results are incorrect if the matrix $\tilde{A}$ is divided into three crisp matrices of lower bounds, middle values and upper bounds, the inverse matrix is calculated separately for each matrix and the inverse matrices are then combined to form an inverse fuzzy matrix (Pandey \& Kumar, 2017). The elements of the inverse fuzzy matrix are not necessarily TFNs since for TFNs the lower bound should be less than or equal to the middle value, which is less than or equal to the upper bound. However, this approach has been employed in many applications of fuzzy DEMATEL (Kiani Mavi \& Standing, 2018; Li et al., 2020; Lin and $\mathrm{Wu}, 2008$; Zhou et al., 2018).
To avoid problems with the inverse fuzzy matrix, defuzzification method to convert fuzzy numbers into crisp numbers is required. Various types of defuzzification approaches have been proposed in the literature. Defuzzification methods should consider the type of fuzzy sets, the shape of the fuzzy numbers, their relative position on the $\mathrm{x}$-axis, the range and height of their membership functions (Opricovic \& Tzeng, 2003). Centroid method with centre of gravity (Yager \& Filev, 1994) is one of the most known methods. A well-known and frequently used one is also the graded mean integration representation (GMIR) (Chen \& Hsieh, 2000), which avoids a zero in the denominator and has been used in several DEMATEL applications (Dong and Huo, 2017; Francés-Chust et al., 2020). Its main disadvantage is that it can convert two fuzzy numbers with different shapes into the same crisp number (Wu \& Lee, 2007). In our study we chose the CFCS method (Converting Fuzzy data into Crisp Scores) (Opricovic \& Tzeng, 2003), which is one of the best known defuzzification methods in fuzzy DEMATEL and has been used in many applications (Chang et al., 2011; Feng \& Ma, 2020; Kazancoglu et al., 2018).

The CFCS of converting fuzzy evaluations into crisp values consists of several stages: first the normalization of the fuzzy numbers, then determination of the left and right normalized scores, the calculation of the crisp values and finally the aggregation of the individual values to a group evaluation by arithmetic mean.

Fuzzy DEMATEL differs from the classic DEMATEL only in the second step. First, linguistic evaluations are converted into corresponding fuzzy numbers. There are several fuzzy scales in the literature. We have selected one (Table 1), which has been 
Table 1. Corresponding relationship between linguistic judgments and fuzzy numbers

\begin{tabular}{ccccc}
\hline $\begin{array}{c}\text { Linguistic } \\
\text { judgments }\end{array}$ & $\begin{array}{c}\text { Corresponding } \\
\text { crisp number }\end{array}$ & $\begin{array}{c}\text { Corresponding } \\
\text { triangular fuzzy } \\
\text { number }\end{array}$ & $\begin{array}{c}\text { Corresponding intuitionistic fuzzy } \\
\text { number }\end{array}$ & $\begin{array}{c}\text { Corresponding } \\
\text { neutrosophic fuzzy } \\
\text { number }\end{array}$ \\
\hline $\begin{array}{c}\text { No } \\
\text { influence }\end{array}$ & 0 & $(0,0,0.25)$ & $((0,0,0,0),(0,0,0,0))$ & $((0,0,0) ; 0.5,0.5,0.5)$ \\
$\begin{array}{c}\text { Very low } \\
\text { influence } \\
\text { Low }\end{array}$ & 1 & $(0,0.25,0.5)$ & $((0,0.1,0.2,0.3)$, & $((0,1,2) ; 0.3,0.75,0.7)$ \\
$\begin{array}{c}\text { influence } \\
\text { High }\end{array}$ & 2 & $(0.25,0.5,0.75)$ & $((0.3,0.4,0.5,0.6),(0.2,0.4,0.5,0.7))$ & $((1,2,3) ; 0.8,0.15,0.2)$ \\
influence \\
$\begin{array}{l}\text { Very high } \\
\text { influence }\end{array}$
\end{tabular}

used in many applications (Dong \& Huo, 2017; Feng \& Ma, 2020; Patil \& Kant, 2014).

Fuzzy evaluations from experts are collected in direct fuzzy matrices $Z^{k}=\left[z^{k}{ }_{i j}\right]$. The matrices are then defuzzified and the individual evaluations are aggregated to group evaluations using CFCS procedure, resulting in a group direct crisp matrix $D=\left[d_{i j}\right]$.

\subsection{Intiutionistic fuzzy sets and intuitionistic DEMATEL}

Intuitionistic fuzzy set theory was proposed by Atanassov (1986). Intuitionistic trapezoidal fuzzy numbers are the continuous extensions of the intuitionistic fuzzy sets. The main advantage of the intuitionistic fuzzy set theory compared to the traditional fuzzy set theory is the ability to take into account the hesitancy degree of experts (Govindan et al., 2015) and deal with vagueness and uncertainty better.

An intuitionistic fuzzy set $\tilde{A}$ in $X$ is characterized by a membership function $\mu_{\tilde{A}}(x)$ representing the grade of membership of the element $x$ in $\tilde{A}$ and by a nonmembership function $v_{\tilde{A}}(x)$ representing the grade of non-membership of the element $x$ in $\tilde{A}$.

$$
\begin{aligned}
& \tilde{A}=\left\{\left(x, \mu_{\tilde{A}}(x), v_{\tilde{A}}(x)\right) \mid x \in X\right\}, \\
& \mu_{\tilde{A}}(x): X \rightarrow[0,1], \\
& v_{\tilde{A}}(x): X \rightarrow[0,1], \\
& 0 \leq \mu_{\tilde{A}}(x)+v_{\tilde{A}}(x) \leq 1, x \in X
\end{aligned}
$$

Let $A=\left(\left(a_{1}, a_{2}, a_{3}, a_{4}\right),\left(b_{1}, b_{2}, b_{3}, b_{4}\right)\right)$ be an intuitionistic trapezoidal fuzzy number. The expected crisp value of $A$ can be calculated as (Grzegrorzewski, 2003):

$$
E V(\tilde{A})=\frac{1}{8}\left(a_{1}+a_{2}+a_{3}+a_{4}+b_{1}+b_{2}+b_{3}+b_{4}\right)
$$

In the intuitionistic DEMATEL, linguistic evaluations are converted into corresponding intuitionistic trapezoidal fuzzy numbers (Table 1) (Gan \& Luo, 2017; Govindan et al., 2015; Nikjoo \& Saeedpoor, 2014; Vafadarnikjoo et al., 2016) in the second step.

Intuitionistic assessments by $m$ experts are recorded in direct intuitionistic matrices $I k=\left[i_{i j}{ }_{i j}\right.$. Then, the expected crisp values $d^{k}{ }_{i j}$ of the intuitionistic evaluations $i_{i j}$ are calculated (eq. 8, Table 2) and the individual values are aggregated to group evaluations with arithmetic mean, resulting in a group direct crisp matrix $D=\left[d_{i j}\right]$. 
Table 2. Expected crisp values

\begin{tabular}{cccc}
\hline Linguistic term & Mark & $\begin{array}{c}\text { Expected crisp } \\
\text { values - intuitionistic }\end{array}$ & $\begin{array}{c}\text { Expected crisp } \\
\text { values - neutrosophic }\end{array}$ \\
\hline No influence & NI & 0 & 0 \\
Very low influence & VLI & 0.15 & 0.84 \\
Low influence & LI & 0.45 & 2.14 \\
High influence & HI & 0.85 & 3.26 \\
Very high influence & VHI & 1 & 4.5 \\
\hline
\end{tabular}

\subsection{Neutrosophic fuzzy sets and neutrosophic DEMATEL}

Smarandache (1998) proposed the neutrosophic set theory to improve the intuitionistic fuzzy set theory. Neutrosophy deals with vagueness and uncertainty and attend the indeterminacy of values. Using the indeterminacy degree, neutrosophic set theory offers the possibility to represent unknown information in our model, so that the experts can give opinions about the uncertain preferences. With neutrosophic set theory we can show the disagreement of the experts. Neutrosophy considers all aspects of decision-making situations by considering truthiness, indeterminacy and falsity in their entirety.

Let $X$ be a space of objects, with a generic element of $X$ denoted by $x$. A neutrosophic fuzzy set $\tilde{A}$ in $X$ is characterized by a truemembership function $T_{\tilde{A}}(x)$, by a indeterminacy-membership function $I_{\tilde{A}}(x)$ and a falsity-membership function $F_{\tilde{A}}(x)$ of element $x$ in $\tilde{A}$.

$$
\begin{aligned}
& \tilde{A}=\left\{\left(x, T_{\tilde{A}}(x), I_{\tilde{A}}(x), F_{\tilde{A}}(x)\right) \mid x \in X\right\}, \\
& T_{\tilde{A}}(x): X \rightarrow[0,1], \\
& I_{\tilde{A}}(x): X \rightarrow[0,1], \\
& F_{\tilde{A}}(x): X \rightarrow[0,1], x \in X
\end{aligned}
$$

with $0 \leq T_{\tilde{A}}(x)+I_{\tilde{A}}(x)+F_{\tilde{A}}(x) \leq 3, x \in X$.
Let $\alpha_{\tilde{A}}, \beta_{\tilde{A}}, \gamma_{\tilde{A}} \in[0,1]$ and $a_{1}, a_{2}, a_{3}, a_{4} \in \mathrm{R}$, with $a_{1} \leq a_{2} \leq a_{3} \leq a_{4}$. The single valued trapezoidal neutrosophic number $\tilde{A}=\left(\left(a_{1}, a_{2}, a_{3}, a_{4}\right) ; \alpha_{\tilde{A}}, \beta_{\tilde{A}}, \gamma_{\tilde{A}}\right)$ is a special neutrosophic set on the real line set $\mathrm{R}$, with truth-membership, indeterminacymembership and falsity membership functions. The expected crisp value can be calculated by the following equation:

$$
E V(\tilde{A})=\frac{1}{8}\left[a_{1}+b_{1}+c_{1}\right]\left(2+\alpha_{\tilde{A}}-\beta_{\tilde{A}}+\gamma_{\tilde{A}}\right)
$$

In neutrosophic DEMATEL, linguistic evaluations are converted into corresponding neutrosophic numbers (Table 1) (Montalvo Pantoja et al., 2020) in the second step.

Fuzzy evaluations from experts are collected in direct neutrosophic matrices $N^{k}=\left[n_{i j}^{k}\right]$. Then the expected crisp values $d^{k}{ }_{i j}$ of the intuitionistic evaluations $n_{i j}^{k}$ are calculated (Eq. 10, Table 2) and the aggregation of individual values to group evaluations with arithmetic mean are provided, resulting in a group direct crisp matrix $D=\left[d_{i j}\right]$.

\section{CASE STUDY}

The aim of including the fuzziness in DEMATEL is to be able to express human thinking more accurately. To investigate how the described differences influence the final results of decision making process, we provided a case study. For the case study we 
Table 3. The pairwise comparisons of criteria: technical, external, organizational and project management of seven experts (NI - no influence, VLI-very low influence, LI-low influence, $H I$ - high influence, VHI - very high influence)

\begin{tabular}{ccccc}
\hline ex 1 & T & E & O & PM \\
\hline T & NI & HI & LI & VHI \\
\hline $\mathbf{E}$ & LI & NI & LI & LI \\
\hline $\mathbf{O}$ & VLI & LI & NI & LI \\
\hline PM & VLI & LI & LI & NI \\
\hline
\end{tabular}

\begin{tabular}{ccccc}
\hline ex 2 & $\mathbf{T}$ & $\mathbf{E}$ & $\mathbf{O}$ & $\mathbf{P M}$ \\
\hline $\mathbf{T}$ & NI & VLI & HI & VHI \\
\hline $\mathbf{E}$ & HI & NI & LI & HI \\
\hline $\mathbf{O}$ & VHI & VLI & NI & HI \\
\hline PM & VHI & VLI & VHI & NI \\
\hline
\end{tabular}

\begin{tabular}{ccccc}
\hline ex 3 & T & E & O & PM \\
\hline $\mathbf{T}$ & NI & NI & NI & VLI \\
\hline $\mathbf{E}$ & HI & NI & HI & VHI \\
\hline $\mathbf{O}$ & VLI & LI & NI & VHI \\
\hline PM & HI & LI & VHI & NI \\
\hline
\end{tabular}

\begin{tabular}{ccccc}
\hline ex 4 & T & E & O & PM \\
\hline $\mathbf{T}$ & NI & VHI & LI & VHI \\
\hline $\mathbf{E}$ & VHI & NI & HI & VHI \\
\hline $\mathbf{O}$ & LI & HI & NI & HI \\
\hline PM & VHI & VHI & HI & NI \\
\hline
\end{tabular}

\begin{tabular}{ccccc}
\hline ex 5 & T & E & O & PM \\
\hline $\mathbf{T}$ & NI & HI & HI & HI \\
\hline $\mathbf{E}$ & HI & NI & VHI & LI \\
\hline O & HI & VHI & NI & VHI \\
\hline PM & HI & LI & VHI & NI \\
\hline
\end{tabular}

\begin{tabular}{ccccc}
\hline ex 6 & T & E & O & P \\
\hline $\mathbf{T}$ & NI & LI & HI & HI \\
\hline $\mathbf{E}$ & LI & NI & LI & LI \\
\hline O & HI & LI & NI & HI \\
\hline PM & HI & LI & HI & NI \\
\hline
\end{tabular}

\begin{tabular}{ccccc}
\hline ex 7 & $\mathbf{T}$ & $\mathbf{E}$ & $\mathbf{O}$ & $\mathbf{P}$ \\
\hline $\mathbf{T}$ & NI & HI & VHI & HI \\
\hline $\mathbf{E}$ & HI & NI & HI & HI \\
\hline $\mathbf{O}$ & VLI & VLI & NI & LI \\
\hline PM & VLI & VLI & LI & NI \\
\hline
\end{tabular}

selected a DEMATEL application from the literature: An Intuitionistic Fuzzy-Based DEMATEL to Rank Risk of Construction Project (Vafadarnikjoo et al., 2016). The framework of the study was the risk breakdown structure, which consists of the groups of common project risks: technical $(\mathrm{T})$, external $(\mathrm{E})$, organizational $(\mathrm{O})$ and project management (PM). Seven experts with appropriate knowledge and experience in project management in different projectbased organizations were selected to evaluate the relationship between the risk groups using a five-level linguistic rating scale (Table 1). Table 3 presents linguistic evaluations of all seven experts.

The linguistic evaluations were then converted into crisp values, TFNs, trapezoidal intuitionistic numbers and neutrosophic numbers according to Table 1 and DEMATEL was used to calculate prominence and relation values and the weights of criteria.

\section{RESULTS AND DISCUSION}

Table 4 shows prominence and relation values as well as the weights of the criteria obtained by DEMATEL, using different types of fuzzy numbers. The results show that the weights are equal for all types of fuzzy evaluations. The prominence and the relation values differ but the graphical representation (Figure 1) shows that cause criteria (with positive values) and effect criteria (with negative values) are the same. There is only a translation in values, but the relationships between the criteria are similar.

Since decision makers are only interested 
Table 4. The prominence and relation values calculated by different fuzzy sets and the weights of criteria

\begin{tabular}{ccccccccccc}
\hline & \multicolumn{2}{c}{ classic } & \multicolumn{2}{c}{ fuzzy } & \multicolumn{2}{c}{ intuitionistic } & \multicolumn{2}{c}{ neutrosophic } & \multirow{2}{*}{ weight } \\
\cline { 2 - 9 } & $\mathbf{R}+\mathbf{C}$ & $\mathbf{R}-\mathbf{C}$ & $\mathbf{R}+\mathbf{C}$ & $\mathbf{R}-\mathbf{C}$ & $\mathbf{R}+\mathbf{C}$ & $\mathbf{R}-\mathbf{C}$ & $\mathbf{R}+\mathbf{C}$ & $\mathbf{R}-\mathbf{C}$ & \\
\hline Technical (T) & 26.05 & 0.23 & 28.94 & 0.27 & 19.51 & 0.35 & 23.21 & 0.35 & 0.25 \\
External (E) & 25.09 & 2.65 & 27.89 & 2.75 & 18.37 & 2.54 & 22.33 & 2.60 & 0.24 \\
Organizational (O) & 26.14 & -1.37 & 28.99 & -1.44 & 19.29 & -1.39 & 23.35 & -1.45 & 0.25 \\
Project management (PM) & 27.65 & -1.51 & 30.57 & -1.57 & 20.42 & -1.50 & 24.79 & -1.50 & 0.26 \\
\hline
\end{tabular}

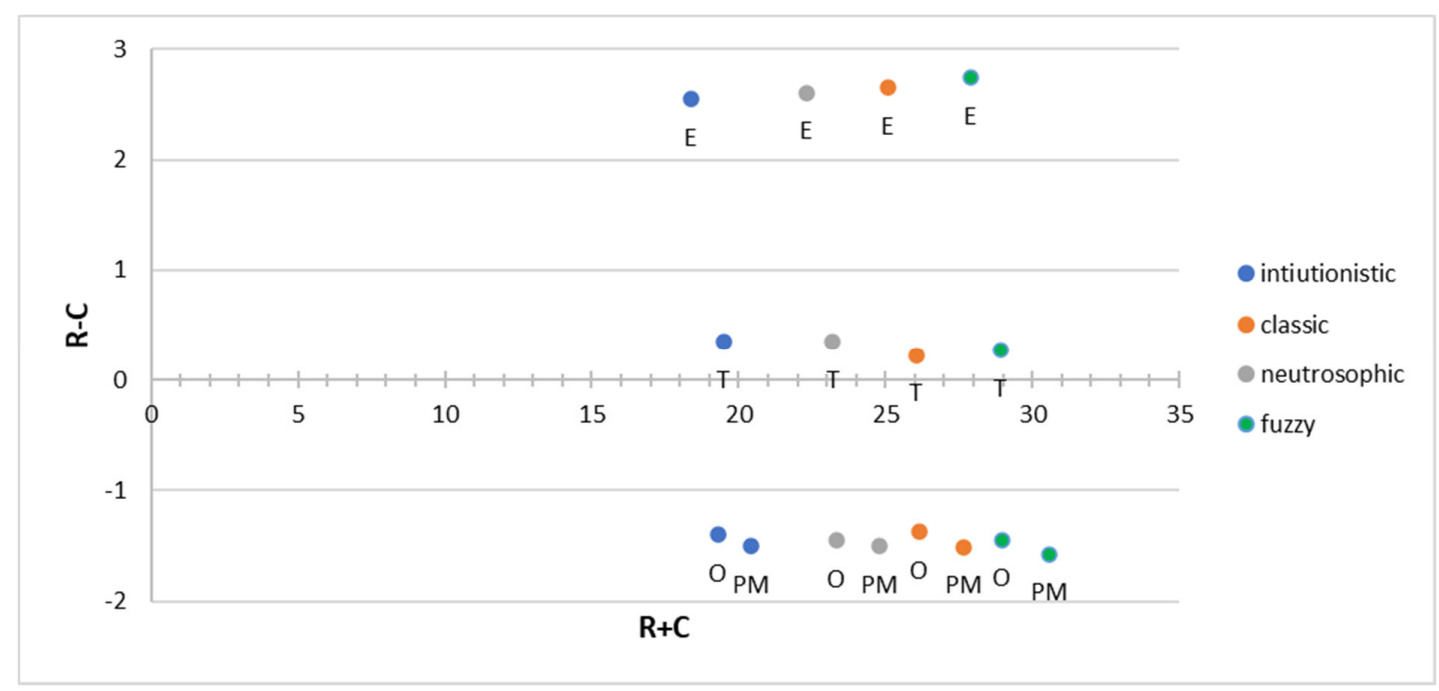

Figure 1. The cause (positive values) and effect (negative values) criteria calculated by different fuzzy sets

in the relationships between the criteria, we can conclude that there is no difference in the type of fuzzy numbers used in the evaluations. The main reason is that the use of fuzzy, intuitionistic or neutrosophic numbers in DEMATEL is limited to the second step. Linguistic judgments provided by experts are converted into TFNs, trapezoidal intuitionistic numbers or neutrosophic numbers. They are immediately defuzzified into crisp numbers before further DEMATEL calculations are performed. Therefore, the only difference between the different types of fuzzification are different crisp values resulting from the defuzzification formulas. We can conclude that it does not matter what type of evaluations (crisp, fuzzy, intuitionistic or neutrosophic) are used in DEMATEL. It is true that more sophisticated types of fuzziness can express human thinking more precisely, but they are also more complicated and more difficult for decision makers to understand. However, their sophistication is lost in defuzzification process in the early phase of DEMATEL. It is therefore unnecessary to use them and we recommend using crisp or TFNs evaluations in DEMATEL. 


\section{CONCLUSIONS}

This study shows how uncertainty and vagueness of decision problems, human thinking and evaluations of decision makers can be included in DEMATEL. It describes how different types of fuzzy sets can be included in DEMATEL. The data for the case study were taken from the literature (Vafadarnikjoo et al., 2016). Seven experts compared the four criteria linguistically. Their linguistic assessments were converted into different types of fuzzy numbers. Then the prominence values, relation values and the weights were calculated by DEMATEL method. The causal diagram was presented. We found that the weights calculated with different types of fuzzy sets are the same and that the relations between prominence and relation values are very similar.
We concluded that the results are the consequence of early defuzzification in DEMATEL and recommended using crisp or TFNs evaluations in DEMATEL since the use of more sophisticated intuitionistic or neutrosophic evaluations does not contribute anything to the final results.

In the future research more in-depth analyses should be performed and more applications evaluated to confirm our results.

\section{Acknowledgement}

The authors acknowledge the financial support from the Slovenian Research Agency (ARRS) within the framework of research program P4-0059 and program young researcher.

\title{
УКЉУЧИВАЊЕ НЕСИГУРНОСТИ СА РАЗЛИЧИТИМ ВРСТАМА ФАЗИ БРОЈЕВА У "DЕМАТЕL"
}

\author{
Tjaša Šmidovnik, Petra Grošelj
}

\section{Извод}

Данас је вишекритеријумско одлучивање веома компликовано због неизвесности, нејасноће, ограничених извора, знања и времена. Лабораторије за тренирање и оцењивање метода одлучивања (DEMATEL) је широко коришћена метода вишекритеријумског одлучивања за анализу структуре сложеног система. Корисна је у анализи узрочно-последичне везе између компоненти система. Фази скупови се могу користити за укључивање несигурности у вишекритеријумско одлучивање. Лингвистичке процене доносилаца одлука могу се превести у фази бројеве. У овој студији су за процену доносилаца одлука у "DEMATEL" методи коришћени фази бројеви, интуиционистички фази бројеви и неутрософски фази бројеви. Циљ ове студије био је да процени како различите врсте фази бројева утичу на коначне резултате. Примена ризика у грађевинским пројектима, као пример, одабрана је из литературе, где је седам стручњака користило лингвистичку скалу за процену различитих критеријума. Резултати су показали да постоје само мале разлике између пондера критеријума с обзиром на врсту фази бројева.

Кључне речи: DEMATEL, фази скупови, интуиционистички фази скупови, неутрософски фази скупови 


\section{References}

Atanassov, K. T. (1986). Intuitionistic fuzzy sets. Fuzzy Sets and Systems, 20, 8796.

Baykasoğlu, A., Kaplanoğlu, V., Durmuşoğlu, Z. D. U., \& Şahin, C. (2013). Integrating fuzzy DEMATEL and fuzzy hierarchical TOPSIS methods for truck selection. Expert Systems with Applications, 40, 899-907.

Chang, B., Chang, C.-W., \& Wu, C.-H. (2011). Fuzzy DEMATEL method for developing supplier selection criteria. Expert Systems with Applications, 38, 1850-1858.

Chen, S. H., \& Hsieh, C. H. (2000). Representation, ranking, distance, and similarity of LR type fuzzy number and application. Australian Journal of Intelligent Processing Systems, 6, 217-229.

Chen, Z., \& Yang, W. (2011). An MAGDM based on constrained FAHP and FTOPSIS and its application to supplier selection. Mathematical and Computer Modelling, 54, 2802-2815.

Dong, J., \& Huo, H. (2017). Identification of Financing Barriers to Energy Efficiency in Small and MediumSized Enterprises by Integrating the Fuzzy Delphi and Fuzzy DEMATEL Approaches. Energies, 10 (8), 1172.

Feng, C., \& Ma, R. (2020). Identification of the factors that influence service innovation in manufacturing enterprises by using the fuzzy DEMATEL method. Journal of Cleaner Production, 253, 120002.

Francés-Chust, J., Brentan, B. M., Carpitella, S., Izquierdo, J., \& Montalvo, I. (2020). Optimal Placement of Pressure Sensors Using Fuzzy DEMATEL-Based Sensor Influence. Water, 12, 493.

Gabus, A., \& Fontela, E. (1973). Perceptions of the world problematique:
Communication procedure, communicating with those bearing collective responsibility, Geneva, Switzerland: Battelle Geneva Research Centre

Gan, J., \& Luo, L. (2017). Using DEMATEL and intuitionistic fuzzy sets to identify critical factors influencing the recycling rate of end-of-life vehicles in China. Sustainability 9 (10), 1873.

Govindan, K., Khodaverdi, R., \& Vafadarnikjoo, A. (2015). Intuitionistic fuzzy based DEMATEL method for developing green practices and performances in a green supply chain. Expert Systems with Applications, 42, 7207-7220.

Grzegrorzewski, P. (2003). The hamming distance between intuitionistic fuzzy sets. In "Proceedings of the 10th IFSA world congress, Istanbul, Turkey", 30, 35-38.

Kazancoglu, Y., Kazancoglu, I., \& Sagnak, M. (2018). Fuzzy DEMATELbased green supply chain management performance: Application in cement industry. Industrial Management \& Data Systems, 118, 412-431.

Kiani Mavi, R., \& Standing, C. (2018). Critical success factors of sustainable project management in construction: A fuzzy DEMATEL-ANP approach. Journal of Cleaner Production, 194, 751-765.

Li, H., Wang, W., Fan, L., Li, Q., \& Chen, X. (2020). A novel hybrid MCDM model for machine tool selection using fuzzy DEMATEL, entropy weighting and later defuzzification VIKOR. Applied Soft Computing, 91, 106207.

Lin, C.-J., \& Wu, W.-W. (2008). A causal analytical method for group decision-making under fuzzy environment. Expert Systems with Applications, 34, 205-213.

Montalvo Pantoja, R. M., Narváez Ortiz, K. A., Salas, S. G., \& Pico, O. A. (2020). Prioritization internal factors in the 
emergency service of the" Luis Gabriel Dávila" Hospital that cause the reentry of patients within 48 hours, based on neutrosophic DEMATEL. Neutrosophic Sets \& Systems 34, 100-109.

Nikjoo, A. V., \& Saeedpoor, M. (2014). An intuitionistic fuzzy DEMATEL methodology for prioritising the components of SWOT matrix in the Iranian insurance industry. International Journal of Operational Research, 20, 439-452.

Opricovic, S., \& Tzeng, G.-H. (2003). Defuzzification within a multicriteria decision model. International Journal of Uncertainty, Fuzziness and KnowledgeBased Systems, 11, 635-652.

Pandey, A., \& Kumar, A. (2017). Commentary on "Evaluating the criteria for human resource for science and technology (HRST) based on an integrated fuzzy AHP and fuzzy DEMATEL approach". Applied Soft Computing, 51, 351-352.

Patil, S. K., \& Kant, R. (2014). A hybrid approach based on fuzzy DEMATEL and FMCDM to predict success of knowledge management adoption in supply chain. Applied Soft Computing, 18, 126-135.

Sheng-Li, S., Xiao-Yue, Y., Hu-Chen, L., \& Zhang, P. (2018). DEMATEL Technique: A Systematic Review of the State-of-the-Art Literature on Methodologies and Applications. Mathematical Problems in Engineering 2018, 33-67.

Smarandache, F. (1998). Neutrosophy: neutrosophic probability, set, and logic: Analytic Synthesis \& Synthetic Analysis. Reheboth, USA, American Research Press.

Sotoudeh-Anvari, A. (2020). A critical review on theoretical drawbacks and mathematical incorrect assumptions in fuzzy OR methods: Review from 2010 to 2020. Applied Soft Computing, 93, 106354.

Tavana, M., Khalili-Damghani, K., \&
Sadi-Nezhad, S. (2013). A fuzzy group data envelopment analysis model for hightechnology project selection: A case study at NASA. Computers \& Industrial Engineering, 66, 10-23.

Torra, V., \& Narukawa, Y. (2009). On hesitant fuzzy sets and decision. In "2009 IEEE International Conference on Fuzzy Systems", IEEE, 1378-1382.

Vafadarnikjoo, A., Mobin, M., \& Firouzabadi, S. (2016). An intuitionistic fuzzy-based DEMATEL to rank risks of construction projects. In "Proceedings of the 2016 International Conference on Industrial Engineering and Operations Management, Detroit, MI, USA", 23-25.

Wu, W.-W., \& Lee, Y.-T. (2007). Developing global managers' competencies using the fuzzy DEMATEL method. Expert Systems with Applications, 32, 499-507.

Yager, R. R., and Filev, D. P. (1994). Essentials of fuzzy modeling and control. New York, 388, 22-23.

Zadeh, L. A. (1965). Fuzzy sets. Information and Control, 8, 338-353.

Zhou, F., Wang, X., Lim, M. K., He, Y., \& Li, L. (2018). Sustainable recycling partner selection using fuzzy DEMATELAEW-FVIKOR: A case study in small-andmedium enterprises (SMEs). Journal of Cleaner Production, 196, 489-504.

Zhou, Q., Huang, W., \& Zhang, Y. (2011). Identifying critical success factors in emergency management using a fuzzy DEMATEL method. Safety Science, 49, 243-252. 